\title{
The Cytotoxicity of Nitroxyl: Possible Implications for the Pathophysiological Role of NO
}

\author{
David A. Wink,*,1 Martin Feelisch,† J on Fukuto,‡ Danae Chistodoulou,§ David J ourd'heuil," \\ Matthew B. Grisham," Yoram Vodovotz,* J ohn A. Cook,* Murali Krishna,* \\ William G. DeGraff,* SungMee Kim,* J anet Gamson,* and J ames B. Mitchell* \\ *Tumor Biology Section, Radiation Biology Branch, National Cancer Institute, Bethesda, Maryland 20892, †Department of \\ Medicine, Division of Cardiology, Pulmonary Diseases, Heinrich Heine University, 4100 Reustrasse 5, D-40225 Dusseldorf, \\ Federal Republic of Germany, $\neq$ Department of Molecular Pharmacology, University of California, Los Angeles California \\ 90095, §Laboratory of Comparative Carcinogenesis, National Cancer Institute, FRDC, Frederick, Maryland 21702; and \\ 'Department of Molecular and Cellular Physiology, Louisiana State University Medical Center, Shreveport, Louisiana 71130
}

In addition to the broad repertoire of regulatory functions nitric oxide (NO) serves in mammalian physiology, the L-arginine:NO pathway is also involved in numerous pathophysiological mechanisms. While NO itself may actually protect cells from the toxicity of reactive oxygen radicals in some cases, it has been suggested that reactive nitrogen oxide species formed from nitric oxide synthase (NOS) can be cytotoxic. In addition to NO, the one electron reduction product $\mathrm{NO}^{-}$has been proposed to be formed from NOS. We investigated the potential cytotoxic role of nitroxyl (NO ${ }^{-}$), using the nitroxyl donor Angelis's salt, (AS; sodium trioxodinitrate, $\mathbf{N a}_{2} \mathbf{N}_{2} \mathrm{O}_{3}$ ) as the source of $\mathrm{NO}^{-}$. AS was found to be cytotoxic to Chinese hamster V79 lung fibroblast cells over a concentration range of 2$4 \mathrm{mM}$. The presence of equimolar ferricyanide (Fe(III)$\left.\left(\mathrm{CN}_{6}\right)^{3-}\right)$, which converts $\mathrm{NO}^{-}$to NO, afforded dramatic protection against AS-mediated cytotoxicity. Treatment of V79 cells with L-buthionine sulfoximine to reduce intracellular glutathione markedly enhanced AS cytotoxicity, which suggests that GSH is critical for cellular protection against the toxicity of $\mathrm{NO}^{-}$. Further experiments showed that low molecular weight transition metal complexes associated with the formation of reactive oxygen species are not involved in ASmediated cytotoxicity since metal chelators had no effect. However, under aerobic conditions, AS was more toxic than under hypoxic conditions, suggesting that oxygen dramatically enhanced AS-mediated cytotoxicity. At a molecular level, AS exposure resulted in DNA double strand breaks in whole cells, and this effect was

\footnotetext{
${ }^{1}$ To whom correspondence and reprint requests should be addressed. Fax: (301) 480-2238.
}

completely prevented by coincubation of cells with ferricyanide or Tempol. The data in this study suggest that nitroxyl may contribute to the cytotoxicity associated with an enhanced expression of the L-arginine:NO pathway under different biological conditions. 1998 Academic Press

Nitric oxide (NO) has been postulated as a causative agent in a variety of pathophysiological states. However, effects ascribed to NO are often mutually contradictory and have therefore been a source of some confusion (1). For instance, NO, in the presence of oxygen or superoxide, can generate reactive nitrogen oxide species $(\mathrm{RNOS})^{2}$, which can oxidize nitrate, or nitrosate, other biomolecules $(2,3)$. RNOS are proposed to mediate various toxic and cytotoxic mechanisms. In contrast, NO can protect cells from damage caused by reactive oxygen species (ROS) (4-6), as a result of different chemical reactions than those involving RNOS (7-10).

NO participates in chemical reactions associated with both oxidative and nitrosative stress which can have del eterious consequences in vivo. Studies suggest that there exists a balance between $\mathrm{NO}$ and two of the major reactive nitrogen oxide species, dinitrogen trioxide $\left(\mathrm{N}_{2} \mathrm{O}_{3}\right)$ and peroxynitrite $\left(\mathrm{ONOO}^{-}\right)$(11- 13) that can determine the toxicological outcome under

\footnotetext{
${ }^{2}$ Abbreviations used: RNOS, reactive nitrogen oxide species; AS, Angelis's salt; DETAPAC, diethylenetriaminepentaacetic acid; DF , desferrioxime; TPH, tempol-H; NADPH, $\beta$-nicotinamide adenine dinucleotide phosphate; PBS, phosphate-buffered saline; GSH, intracellular glutathione; ER, enhancement ratio; ESR, electron spin resonance.
} 
conditions involving both or either NO and ROS. However, as the NO story unfolds, it becomes clear that other species may be involved in the modulation of physiologic responses. For instance, another often overlooked nitrogen oxide species, nitroxyl $\left(\mathrm{NO}^{-}\right)$, has been thought to participate in the biology of nitric oxide. $\mathrm{NO}^{-}$is the one electron reduction product of NO. Two reports suggest that $\mathrm{NO}^{-}$is formed directly by nitric oxide synthase (NOS) $(14,15)$, the source of NO in mammals. These two reports postulate that the product of NOS is $\mathrm{NO}^{-}$which was then converted to NO by SOD and other suitable electron acceptors. However, NOS also can produce $\mathrm{N}^{\mathrm{G}}$-hydroxy-L-arginine (HO-Arg) (16), which can be oxidized by catalase and hydrogen peroxide to give $\mathrm{NO}^{-}$(17). This would suggest that NOS can produce $\mathrm{NO}^{-}$directly or from precursors such as HO-Arg under oxidative stress. Finally, $\mathrm{NO}^{-}$can be formed under nitrosative stress $(18,19)$. The formation of S-nitrosothiols in the presence of nitrosating agents formed either from the $\mathrm{NO} / \mathrm{O}_{2}$ reaction or the $\mathrm{NO} / \mathrm{O}_{2}{ }^{-}$ reaction can decompose to yield $\mathrm{NO}^{-}$in the presence of excess thiol by reactions described for S-nitrosothiols under acidic conditions (20). Therefore, in biological systems, the formation of $\mathrm{NO}^{-}$can result either directly from the enzymatic activity of NOS, metabolism of the decoupled NOS product HO-Arg under oxidative stress, or under nitrosativestress through the interaction with thiols. Given these diverse pathways to form $\mathrm{NO}^{-}$in vivo, we investigated the effect of $\mathrm{NO}^{-}$on cell survival using Angelis's salt as a spontaneous $\mathrm{NO}^{-}$donor compound.

In our previous reports, NONOate complexes have been used to explore the toxicology of NO $(5,21-25)$. These amine derivatives release NO in a time-dependent fashion when dissolved at neutral $\mathrm{pH}$. Likewise, AS possesses a similar functional group (X-N(O)NO) and also gradually decomposes at neutral $\mathrm{pH}$ to yield $\mathrm{NO}^{-}$instead of NO (26). AS is therefore a useful tool for the investigation of the potential cytotoxic role of $\mathrm{NO}^{-}$. We report here that $\mathrm{NO}^{-}$derived from AS is more toxic than NO under similar conditions. Such findings may provide useful insights which may better define the ambiguities and consequences of NO metabolism and the function of NOS-derived products.

\section{MATERIALS AND METHODS}

Chemicals. Desferrioxamine (DF), diethylenetriaminepentaacetic acid (DETAPAC), $\mathrm{NH}_{2} \mathrm{OH} \cdot \mathrm{HCl}$ potassium ferricyanide, silver nitrate $\left(\mathrm{AgNO}_{3}\right)$, butyl iodine ( $\mathrm{n}$-Bul ), tetrabutylammoninium chloride $\left(\mathrm{NBu}_{4} \mathrm{Cl}\right)$, sodium sulfate $\left(\mathrm{Na}_{2} \mathrm{SO}_{4}\right)$, and Tempol (4-hydroxy-2,2,6,6tetramethyl-1-piperinyloxyl) were purchased from Aldrich (Milwaukee, WI). Tempol-H (the hydroxylamine form of Tempol; TPH) was purchased from Molecular Probes (E ugene, OR). $\beta$-Nicotinamide adenine dinucleotide phosphate (reduced form, NADPH) was purchased from Sigma (St. Louis, MO). AS was prepared by a modification of a previously reported method that used n-Butylnitrate $\left(n-\mathrm{BuONO}_{2}\right)$ and hydroxylamine (27). n-BuONO $\mathrm{N}_{2}$ was prepared at room tempera- ture by the reaction of $\mathrm{AgNO}_{3}\left(50 \mathrm{~g} 294 \mathrm{mmol}\right.$ ) in $100 \mathrm{~mL}$ of $\mathrm{CH}_{3} \mathrm{CN}$ added to $33.3 \mathrm{~mL}$ (294 mmol) of $\mathrm{n}$-Bul in five portions with acetonitrile $\left(\mathrm{CH}_{3} \mathrm{CN}\right)$. The reaction was stirred for $72 \mathrm{~h}$ until a yellow precipitate formed. The solution was filtered though celite ( $80 \mathrm{mg}$ celite in $110 \mathrm{~mL} \mathrm{CH} \mathrm{CH}_{3} \mathrm{CN}$ ) with $\mathrm{CH}_{3} \mathrm{CN}(100 \mathrm{~mL})$. A small fraction of the solution was tested for excess silver by adding tetrabutlyammonium chloride $\left(\mathrm{NBu}_{4} \mathrm{Cl}\right)$. Further $\mathrm{Ag}^{+}$was removed by stirring in the presence of a saturated $\mathrm{NaCl}$ solution. The precipated $\mathrm{AgCl}$ (white solid) was removed by filtration and the organic layer retested for $\mathrm{Ag}^{+}$until no further precipitate was formed. The organic layer was dried over anhydrous $\mathrm{Na}_{2} \mathrm{SO}_{4}$. The filtration of $\mathrm{Na}_{2} \mathrm{SO}_{4}$ gave a clear organic solution. The organic layer was distilled under nitrogen to remove solvent. The remaining residue was pale yellow with a yield of 13.7 g. Next, NaOEt was freshly made by dissolving small pieces of etherrinsed $\mathrm{Na}$ metal $(4.03 \mathrm{~g})$ into ethanol. At the same time $\mathrm{NH}_{2} \mathrm{OH} \cdot \mathrm{HCl}$ $(4.05 \mathrm{~g}, 58 \mathrm{mmol})$ was stirred in heated $\mathrm{EtOH}(35 \mathrm{~mL})$. The ethanolic solution of $\mathrm{NH}_{2} \mathrm{OH} \cdot \mathrm{HCl}$ was added to the solution of $\mathrm{NaOEt}$ and the white solid $(\mathrm{NaCl})$ removed by filtration. To the stirring filtrate was added $\mathrm{n}-\mathrm{BuONO}_{2}(7 \mathrm{~g}, 58 \mathrm{mmol})$. The solution turned light brown, followed then by formation of a white precipitate. The solution was capped and stored at $-20^{\circ} \mathrm{C}$, where a solid formed overnight. The solution was taken in a dry-box, filtered, and washed with diethyl ether $(20 \mathrm{~mL})$ to yield $4.01 \mathrm{~g}$ of crude solid. The resulting filtrate was treated with $100 \mathrm{~mL}$ of diethyl ether and stored at $-30^{\circ} \mathrm{C}$ overnight to obtain additional precipitate. The product was dissolved in $25 \mathrm{~mL}$ $50 \mathrm{mM} \mathrm{NaOH}$ and filtered through celite. $150 \mathrm{~mL}$ EtOH was added and the combined solutions stored at $-20^{\circ} \mathrm{C}$. In 3 days, needle-shaped crystals were formed, which were washed with acetone and dried in an inert (nitrogen) atmosphere at ambient pressure. Purity was determined by the extinction coefficient at $250 \mathrm{~nm}$ in $20 \mathrm{mM} \mathrm{NaOH}$ solution. Stock solutions were made by dissolving AS in $20 \mathrm{mM}$ $\mathrm{NaOH}$ solution as previously described (28).

NADPH measurements. The oxidation of NADPH was assayed by examining the loss of the characteristic absorbance at $340 \mathrm{~nm}$. A phosphate-buffered saline (PBS) solution of NADPH $(100 \mu \mathrm{M})$ containing $0.05 \mathrm{mM}$ DETAPAC and $10 \mathrm{mM}$ Hepes was treated with AS at $37^{\circ} \mathrm{C}$ for $30 \mathrm{~min}$. Peroxynitrite $\left(\mathrm{ONOO}^{-}\right)$was synthesized as previously described (29) and added to NADPH-containing buffer at room temperature. Anaerobic experiments were carried out in sealed-vials with rubber septa which were degassed with nitrogen. DEA/NO $\left(\left(\mathrm{C}_{2} \mathrm{H}_{5}\right)_{2} \mathrm{~N}\left[\mathrm{~N}(\mathrm{O}) \mathrm{NO}^{-} \mathrm{Na}^{+}\right)\right.$was supplied by Dr. J . Saavedra and was prepared as previously described (28).

Cell culture and incubations. Chinese hamster V79 lung fibroblasts were cultured in F 12 medium supplemented with $10 \%$ fetal calf serum and antibiotics. Cell survival was assessed by clonogenic assay; plating efficiencies for $V 79$ cells were $0.74 \pm 0.1$. Stock cultures of exponentially growing cells were trypsinized, rinsed, and plated $\left(7 \times 10^{5}\right.$ cells/dish) into a number of $100 \mathrm{~cm}^{2}$ culture dishes and incubated $16 \mathrm{~h}$ at $37^{\circ} \mathrm{C}$ prior to use in experimental protocols. Cells were exposed to varying concentrations of AS (0-5 mM) for $1 \mathrm{~h}$. Modulation of AS cytotoxicity was studied by various drug additions immediately prior to addition of AS, including equimolar final concentrations of potassium ferricyanide (Fig. 1A), potassium ferricyanide (final concentration of $1 \mathrm{mM}, \mathrm{Fig}$. 2A), or Tempol (TP) (final concentration, $1 \mathrm{mM}$ ) or Tempol-H (TPH) (final concentration, 1 $\mathrm{mM}$ ). Some studies involved pretreatment of cells for $2 \mathrm{~h}$ with desferrioxamine (DF) or DETAPAC at final concentrations of 0.5 or 0.1 $\mathrm{mM}$, respectively. DF and DETAPAC were left on the cells during the 1-h treatment with AS. F or studies involving GSH depletion prior to AS treatment, cells were pretreated with $0.5 \mathrm{mM}$ BSO for $19 \mathrm{~h}$ prior to experimental procedures as described above. In control studies, AS (0-5 mM) was allowed to decompose (denoted as "Decomposed $\mathrm{AS}^{\prime}$ " on survival curves) in full medium overnight at $37^{\circ} \mathrm{C}$ prior to addition to cells. For all treatment conditions, $10 \mathrm{mM}$ Hepes was added to the medium to maintain $\mathrm{pH}$ at 7.2. Following treatment, the cells were washed twice with phosphate-buffered saline (PBS), trypsinized, counted, and plated for macroscopic colony formation. 
For each dose determination, cells were plated into triplicate dishes and each experiment was repeated a minimum of two times. Plates were incubated for 7 days, after which colonies were fixed with methanol/acetic acid (3:1), stained with crystal violet, and counted. Colonies containing $>50$ cells were scored. Error bars represent S.D. of the mean and are shown when larger than the symbol. Survival curves were corrected for plating efficiency and cytotoxicity of the various drugs used where appropriate.

For exposure to AS under hypoxic conditions, cells from exponentially growing stock cultures were plated into specially designed 25 $\mathrm{cm}^{3}$ glass flasks ( $2.5 \times 10^{5}$ cells in $2 \mathrm{~mL}$ of medium flask) equipped with ground glass side arms which, when inverted, could deliver 0.2 $\mathrm{mL}$ of solution of $\mathrm{AS}$ (in $20 \mathrm{mM} \mathrm{NaOH}$ ) or decomposed AS to the culture media and cell monolayer (30). Stoppered flasks connected in series were gassed with a humidified gas mixture of $95 \%$ nitrogen/ $5 \% \mathrm{CO}_{2}$ (Matheson Gas Products) for $1 \mathrm{~h}$ at $37^{\circ} \mathrm{C}$. The gassing procedure resulted in an equilibrium between the gas and liquid phase and yielded oxygen concentrations in the effluent gas phase of $<10$ ppm as measured by a Thermox probe (30). Following the gassing period, the hypoxic AS (or decomposed AS) solution in the side arms was added to the cell monolayer and the cells were exposed to varying concentrations of AS or decomposed AS (1.0-4.0 mM) for $1 \mathrm{~h}$ while maintaining hypoxic conditions. Following treatment, cell survival was assayed as described above. Cells were exposed to the specified agents for $60 \mathrm{~min}$ as described for the cytotoxicity assay, rinsed twice, then evaluated for intracellular GSH. I ntracellular glutathione was measured as previously described (31).

DNA double strand breaks. Cells for electrophoresis were plated as described above, and the DNA was labeled by incubating the cells with $0.02 \mu \mathrm{Ci} / \mathrm{ml}{ }^{14} \mathrm{C}$-thymidine for $24 \mathrm{~h}$ prior to exposure to test compounds. DNA was prepared for electrophoresis as follows (32, 33). After exposure to AS, as well as other combinations of ferricyanide and Tempol, the cells were trypsinized, rinsed, and resuspended in PBS at $10^{7} \mathrm{cell} / \mathrm{s} / \mathrm{ml}$. An equal volume of $1 \%$ low-gelling temperature agarose was added, and the cell suspension was drawn into 3/32 inch (i.d.) silicone tubing with a syringe. Both ends of the tubing were clamped, and the tubing was immersed in an ice bath to rapidly solidify the agarose. The agarose was then extruded from the tubing, cut into 5-mm lengths, and these "plugs" were placed into 1.5-ml centrifuge tubes. The procedure results in approximately $10^{5}$ cells per 5-mm plug. Cellular DNA with the plugs was prepared for electrophoresis by incubating at $55^{\circ} \mathrm{C}$ in ESP buffer $(0.5 \mathrm{M}$ EDTA, $1 \%$ Sarkosyl, and $1 \mu \mathrm{g} / \mathrm{mL}$ proteinase $\mathrm{K}$ ) for $24 \mathrm{~h}$. The plugs were then rinsed in TE buffer ( $10 \mathrm{mM}$ Tris, $1 \mathrm{mM}$ EDTA) for $24 \mathrm{~h}$ with a total of three buffer changes. RNA was digested by incubation with 0.1 $\mu \mathrm{g} / \mathrm{ml}$ boiled RNAse A in TE buffer for $2 \mathrm{~h}$ at $37^{\circ} \mathrm{C}$.

Agarose gels $(0.8 \%)$ were cast in TBE (TBE contained $45 \mathrm{mM}$ Tris, $45 \mathrm{mM}$ boric acid, $1.25 \mathrm{mM}$ EDTA), loaded into $2 \times 6 \times 5-\mathrm{mm}$ wells, and the wells were sealed with melted agarose. Electrophoresis was carried out for $24 \mathrm{~h}$ at 56 volts (4 volts/cm), with a 3:1 ratio of forward to reverse pulse time. The initial forward pulse time was $7.5 \mathrm{~s}$ (reverse pulse $2.5 \mathrm{~s}$ ), increasing to a final forward pulse time of 90 $\mathrm{s}$ (final reverse pulse $30 \mathrm{~s})$. The running buffer $(0.5 \times \mathrm{TBE})$ was recirculated and cooled to maintain a temperature of $12-15^{\circ} \mathrm{C}$. These electrophoresis conditions were chosen based on methods of Stamato and Denko (33), and the desire to keep the released DNA concentrated in a narrow band to facilitate quantitation (see below).

After electrophoresis, the gels were soaked in $0.5 \mu \mathrm{g} / \mathrm{mL}$ ethidium bromide for $30 \mathrm{~min}$, destained with distilled water for $30 \mathrm{~min}$, and photographed on a UV light box. The lanes were separated from one another, and the well containing the plug was separated from the portion of the lane containing the released DNA. These small pieces of agarose were put into separate scintillation vials, and the agarose was melted by placing each vial on a hot plate, after adding $50 \mu \mathrm{L}$ of concentrated $\mathrm{HCl}$ to prevent resolidification of the agarose. Fifteen milliliters of Euoquint (National Diagnostics) was added to each vial, and radioactivity was determined by counting on an Beckman 6500 scintillation counter. The data is expressed as "percentage of DNA remaining in the well" and was calculated as follows:

At least two independent experiments were run for each treatment, with duplicate plugs run at each dose level or control.

Electrochemical determination of NO. The determination of NO produced under different experimental conditions was performed as previously described $(34,35)$. NO determination was evaluated by observing current changes utilizing a Nickel porphyrin/Nafion electrode at $37^{\circ} \mathrm{C}$. However, unlike previous determination of $\mathrm{NO}$ re leased from NONOate (5) and other NO donor compounds (6), AS itself produced significant current under these conditions; $10 \mathrm{nA} / \mathrm{mM}$ AS. To determine whether $\mathrm{NO}$ was produced, oxyhemogl obin $\left(\mathrm{HbO}_{2}\right)$ was used to scavenge NO. Addition of oxyhemoglobin did not alter the observed current with only AS present. Tempol (1 mM) also showed an increase in current $(10 \mathrm{nA} / \mathrm{mM})$. This background was subtracted from the observed current to reflect the changes in current resulting from the interference by $A S$. Experiments (time zero) were initiated by delivery of AS. Ferricyanide or Tempol were added to buffer prior to AS. $\mathrm{HbO}_{2}$ was prepared as previously described by reduction of hemoglobin (Sigma, St. Louis, $\mathrm{MO}$ ) with dithionite and desalted by passage through a Sephadex P-25M column (Pharmacia, Sweden).

\section{RESULTS}

When Chinese hamster V79 lung fibroblast cells were exposed to increasing concentrations of AS for 1 $h$, there was a marked decrease in cell survival (Fig. 1A). If AS was first allowed to decompose (half-life is $2.3 \mathrm{~min}(28)$ ) in media before addition to cells, no appreciable toxicity was observed, which indicates that a transient toxic intermediate derived from AS mediated the observed cytotoxicity (Fig. 1A). Ferricyanide ([Fe(III) $\left.\left.(\mathrm{CN})_{6}\right]^{3-}\right)$ converts AS from a nitrous oxide $\left(\mathrm{N}_{2} \mathrm{O}\right)$ generating compound to an NO generating compound (36). Ferricyanide treatment al one resulted in no cytotoxicity; however, addition of equimolar AS and ferricyanide resulted in marked protection against AS-induced toxicity, suggesting that the electron acceptor [Fe(III) $\left.(\mathrm{CN})_{6}\right]^{3-}$ neutralizes the toxic intermediate derived from AS (Fig. 1A). To further determine the influence of other electron acceptor compounds on AS-mediated toxicity, cells were treated with and without addition of the superoxide dismutase-mimic, Tempol (37). Simultaneous treatment of cells with AS and Tempol (final concentration $1.0 \mathrm{mM}$ ) resulted in significant protection against AS-induced cytotoxicity (Fig. 1B). When the same experiment was repeated with the one-electron reduction product of Tempol, TPH (final concentration $1.0 \mathrm{mM}$ ), no protection was observed (Fig. 1B).

The marked protection by the one electron oxidants, ferricyanide and Tempol, can be explained by the conversion of AS from a nitroxyl donor to an NO donor. To verify this, the presence of NO was evaluated using a Ni porphyrin/Nafion-coated electrode. When $0.1 \mathrm{mM}$ AS was allowed to decompose in PBS buffer at $37^{\circ} \mathrm{C}$, there was an immediate increase in current that decreased in a fashion consistent with the decomposition kinetics expected for AS under these conditions. To determine if $\mathrm{NO}$ was present, $\mathrm{HbO}_{2}$ was added. Addition 


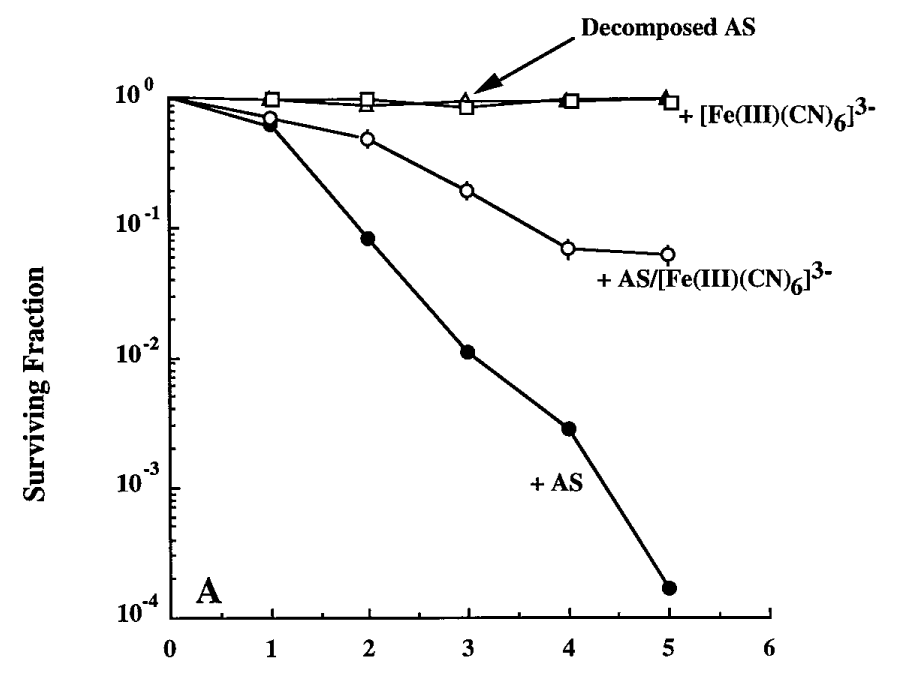

NO (Fig. 2B). Control experiments showed that both Tempol and its one electron reduced product TPH produce current under the above experimental conditions (10 nA/mM); however, exposure of $\mathrm{HbO}_{2}$ did not alter the current. This control experiment eliminated the possibility of the reduction in current being due to a reaction between Tempol or TPH and $\mathrm{HbO}_{2}$. Taken together, the results clearly show that there was increased NO production from AS in the presence of either ferricyanide or Tempol.

The next series of experiments involved exploring factors that might influence AS cytotoxicity. I ntracellu-

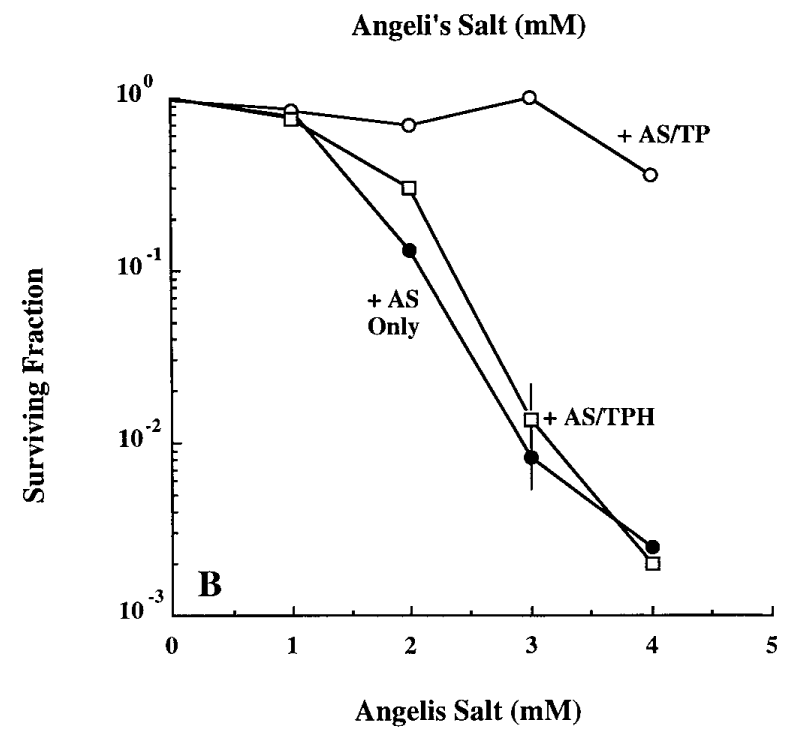

FIG. 1. Cell survival of V79 cells exposed to varying concentrations of AS for $1 \mathrm{~h}$ in the presence or absence of equimolar concentrations of ferricyanide $\left(\mathrm{Fe}(\mathrm{III})(\mathrm{CN})_{6}^{-3}\right)(\mathrm{A})$; or a final concentration of $1.0 \mathrm{mM}$ Tempol or the corresponding one electron reduction product TPH (B). AS or decomposed AS was exposed to cells for a period of $1 \mathrm{~h}$ at $37^{\circ} \mathrm{C}$.

of $3.5 \mu \mathrm{M} \mathrm{HbO}$ had no effect on the electrochemical signal, which suggested that no detectable NO was produced. The same experiment was then conducted in the presence of $1 \mathrm{mM}$ ferricyanide. As shown in Fig. 2A, there was a dramatic increase in signal which could be attributed to the presence of NO. To verify this, 3.5 $\mu \mathrm{M} \mathrm{HbO}$ was added to the solution after which the electrochemical signal decreased (Fig. 2A). Such observations confirmed the formation of NO under these conditions. When an analogous experiment was performed with $1 \mathrm{mM}$ Tempol, there again was an increase in current (Fig. 2B). Addition of $3.5 \mu \mathrm{M} \mathrm{HbO}_{2}$ resulted in decrease in signal again substantiating the presence of

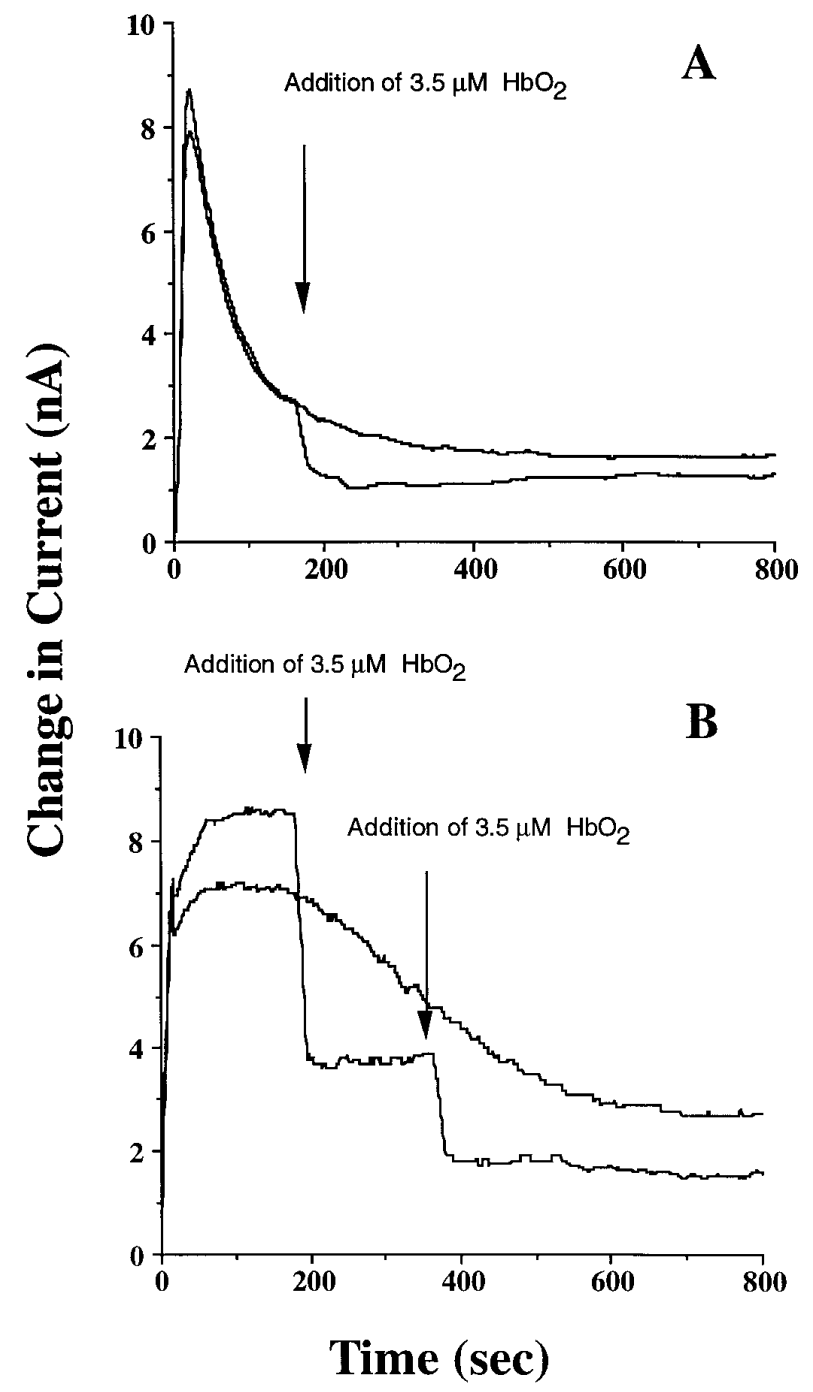

FIG. 2. Electrochemical detection of $N O$ in the presence of $A S$ with ferricyanide or Tempol. AS $(0.1 \mathrm{mM})$ was added to PBS buffer at $37^{\circ} \mathrm{C}$ containing either $1 \mathrm{mM}$ ferricyanide $(A)$ or $1 \mathrm{mM}$ Tempol (B). $3.5 \mu \mathrm{M} \mathrm{HbO}_{2}$ was added to verify $\mathrm{NO}$ was present. Addition of $\mathrm{HbO}_{2}$ did not alter the observed changes in current with AS present only. Therefore, the baseline due to AS decay was subtracted from the current changes observed in the presence of ferricyanide or Tempol. The NO $\mu \mathrm{M}$ per current changes was $1.7 \mu \mathrm{M} / \mathrm{nA}$. 
Iar glutathione (GSH) is a critical part of the cellular detoxification network against a variety of chemical insults mediated by reactive chemical species. To determine if GSH affected the cytotoxicity of AS, V79 cells were treated with BSO for $19 \mathrm{~h}$ to deplete intracellular GSH levels prior to treatment with AS. Using these conditions, BSO treatment al oneresulted in no cytotoxicity and reduced intracellular GSH levels to $<5 \%$ of control values (data not shown). When the BSO-treated cells were exposed to increasing concentrations of AS, there was a marked enhancement in cytotoxicity over that observed for AS treatment alone, with an enhancement ratio (ER) of 2.2 at the $1 \%$ survival level (Fig. $3 A$ ). As demonstrated in Fig. $1 \mathrm{~A}$, $\left[\mathrm{F} \mathrm{e}(\mathrm{III})(\mathrm{CN})_{6}\right]^{3-}$ treatment alone was not cytotoxic; however, cotreatment of BSOtreated cells with $\mathrm{AS}$ and $\left[\mathrm{Fe}(\mathrm{III})(\mathrm{CN})_{6}\right]^{3-}$ resulted in marked protection against cytotoxicity induced by AS (Fig. 3A).

Since oxygen could react with $\mathrm{NO}^{-}$to potentially form a variety of RNOS that might cause cellular damage, the influence of oxygen on AS cytotoxicity was evaluated. Cells were therefore maintained under hypoxic conditions and exposed to varying concentrations of AS for $1 \mathrm{~h}$ and the cytotoxicity was evaluated (Fig. 3B). AS treatment under hypoxic conditions exhibited modest cytotoxicity; however, the cytotoxicity was much less when compared to aerobic AS treatment. The products from decomposed AS resulted in no cytotoxicity if treatment was conducted under hypoxic conditions. The results show that oxygen enhanced the cytotoxicity of AS to V79 cells. One possible explanation for these results could involve ROS derived from metalbased Fenton chemistry. We therefore evaluated cytotoxicity in V79 fibroblast cells induced by AS in the presence of the metal chelators, desferrioxamine and DETAPAC. Under aerobic conditions, neither of these agents afforded significant protection against AS cytotoxicity (Fig. 4). The concentrations of metal chelators used were sufficient to prevent cellular damage and death mediated by Fenton-derived ROS (37). Therefore, these findings suggest a limited role for metals in the cytotoxicity of AS.

Since depletion of GSH was associated with an increased toxicity of AS, changes in the intracellular GSH levels were examined after exposure to AS. Exposure of $1 \mathrm{mM} \mathrm{AS}$ to $\mathrm{V} 79$ cells for $60 \mathrm{~min}$ resulted in a decrease in intracellular GSH levels by $75 \%$ (Table I). In the presence of $3 \mathrm{mM}$ AS, no detectable GSH was observed. In contrast, treatment with DEA/NO re sulted in a decrease of only $25 \%$ in intracellular GSH (25). Treatment of V79 cells with solution of decomposed AS, which contains primarily nitrite and $\mathrm{N}_{2} \mathrm{O}$, reduced intracellular levels of GSH by $25 \%$ (Table I). However, when cells were treated with AS in the presence of ferricyanide or Tempol, depletion of GSH was modest. It is clear that AS considerably reduces intra-
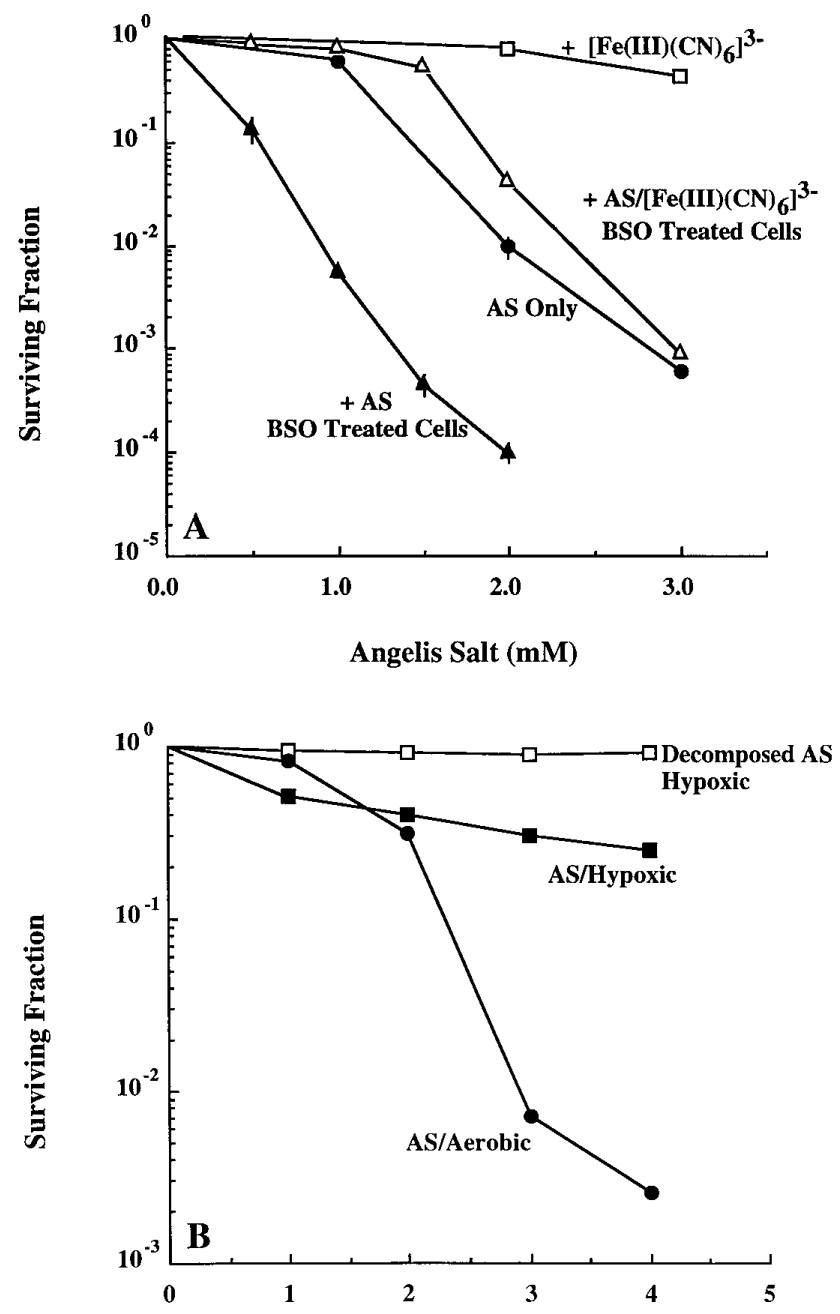

Angeli's Salt (mM)

FIG. 3. (A) Cell survival of V79 cells exposed to varying concentrations of AS for $1 \mathrm{~h}$ in the presence or absence of BSO pretreatment or with and without ferricyanide $\left(\mathrm{Fe}(\mathrm{III})(\mathrm{CN})_{6}^{-3}\right)$. (B) Cell survival of $V 79$ cells exposed to varying concentrations of AS for $1 \mathrm{~h}$ under aerobic or anoxic conditions.

cellular GSH; however, such reduction in GSH levels can be prevented by one electron acceptors.

Treatment of $\mathrm{V} 79$ cells with AS resulted in DNA double strand breaks as shown in Figs. 5A and 5B. Either Tempol or $\left[\mathrm{Fe}(\mathrm{III})(\mathrm{CN})_{6}\right]^{3-}$ added at equimolar concentrations completely abol ished the double strand breaks caused by AS; whereas, Tempol-H did not. Our findings would indicate that DNA double strand breaks resulting from AS exposure may be the direct result of nitroxyl toxicity. Likewise, the reversal of AS-mediated DNA double strand breaks by $\left[\mathrm{Fe}(\mathrm{III})(\mathrm{CN})_{6}\right]^{3-}$ and Tempol correlates with their ability to provide protection against the cytotoxicity of AS (Figs. $1 A$ and $1 B$ ).

We next examined the AS-mediated oxidative chemistry by adding AS to solutions containing NADPH. 


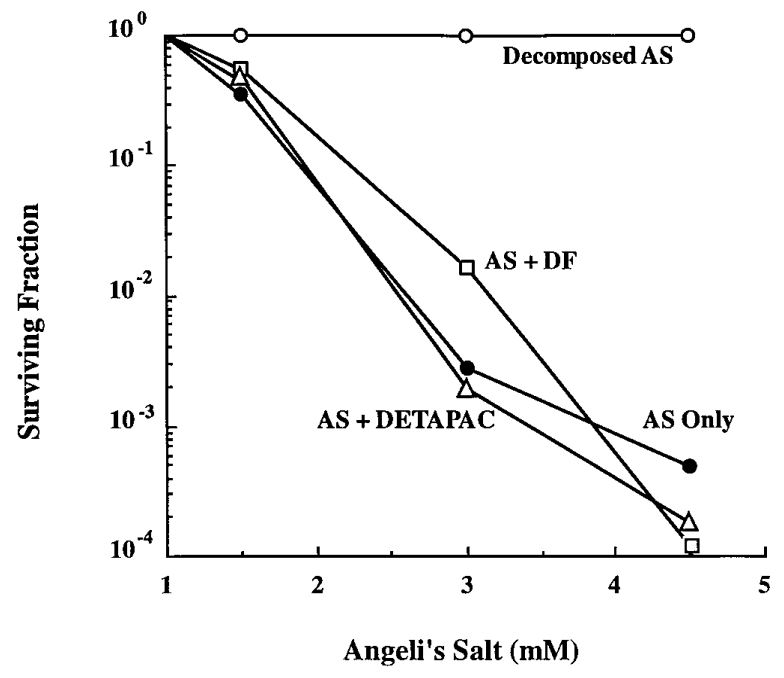

FIG. 4. Cell survival of V79 cells exposed to varying concentrations of AS for $1 \mathrm{~h}$ in the absence of presence of pretreatment with 0.1 mM DF (final concentration, $0.5 \mathrm{mM}$ ) or DETAPAC (final concentration, $0.1 \mathrm{mM}$ ).

NADPH can undergo two-electron oxidation to form $\mathrm{NADP}^{+}$. This oxidation can be measured by observing the loss of characteristic absorbance peak of NADPH at $340 \mathrm{~nm}$. When solutions of NADPH were exposed to increasing amounts of AS, NADPH oxidation was observed (Fig. 6). Experiments using $0.2 \mathrm{mM}$ AS under anaerobic conditions resulted in slightly less oxidation of NADPH, which indicates that oxidation may occur through either $\mathrm{NO}^{-}$or some other RNOS (Fig. 6). NADPH oxidation was also prevented by $0.5 \mathrm{mM}$ Tempol (Fig. 6), again consistent with the data shown in Fig. 1B. Ferricyanide could not be used in this particular

TABLE I

Effect of AS on Intracellular GSH Levels ${ }^{a}$

\begin{tabular}{lc}
\hline \multicolumn{1}{c}{ Conditions } & Percentage of $\mathrm{GSH}^{\mathrm{b}}$ \\
\hline Control $^{\mathrm{c}}$ & $100+3$ \\
AS & $25+4$ \\
Ferricyanide & $82+6$ \\
AS + Ferricyanide & $66+6$ \\
Rel AS & $75+6$ \\
Tempol & $118+4$ \\
AS Tempol & $60+6$ \\
AS (3 mM) & $\mathrm{N} . \mathrm{D} . \mathrm{d}^{\mathrm{m}}$ \\
AS (3 mM) + Tempol & $7+2$ \\
TPH & $101+9$ \\
AS + TPH & $21+0.3$ \\
\hline
\end{tabular}

a AS, ferricyanide, tempol, and TPH were done at $1 \mathrm{mM}$ unless otherwise indicated.

${ }^{\mathrm{b}}$ Experiments were conducted in triplicate.

' Total GSH was $0.7 \mu \mathrm{g}$ per $10^{6}$ cells.

d No detection.
A

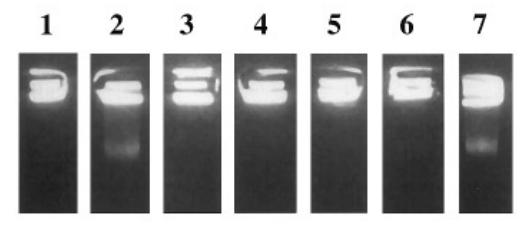

B

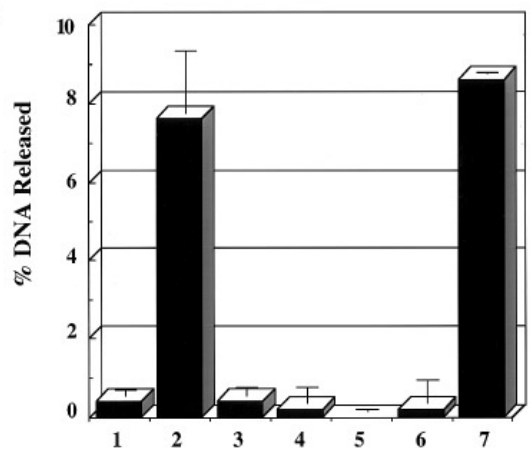

FIG. 5. (A) Field inversion electrophoresis gel of DNA extracted from V79 cells treated with 4 mM AS (or decomposed AS) for $1 \mathrm{~h}$ in the absence or presence of $4.0 \mathrm{mM}$ ferricyanide, $1.0 \mathrm{mM}$ Tempol, or $1.0 \mathrm{mM}$ Tempol-H. Column numbers correspond to: 1 , control; 2 , AS alone; 3, decomposed AS alone; 4, ferricyanide alone; 5, ferricyanide + AS; 6, Tempol + AS; 7, Tempol-H + AS. Treatment of cells with Tempol or Tempol-H alone resulted in no DNA damage, data not shown. (B) Quantitation of DNA damage (expressed as percentage of DNA released) of conditions shown in $A$. Column numbers on the $\mathrm{x}$-axis correspond to column numbers in $\mathrm{A}$.

assay because it oxidized NADPH. One possible chemical intermediate in the decomposition of AS is peroxynitrite $\left(\mathrm{ONOO}^{-}\right)$derived from the reaction between $\mathrm{NO}^{-}$ and oxygen. Peroxynitrite at $0.2 \mathrm{mM}$ also oxidized NADPH (Fig. 6); however, Tempol did not prevent the peroxynitrite-mediated oxidation of NADPH, suggesting that Tempol acts by scavenging $\mathrm{NO}^{-}$, not $\mathrm{ONOO}^{-}$. Hydroxylamine $\left(\mathrm{NH}_{2} \mathrm{OH}\right)$, which has been shown to scavenge $\mathrm{NO}^{-}$, also prevented NADPH oxidation mediated by AS. However, hydroxylamine did not prevent NADPH oxidation meditated by $\mathrm{ONOO}^{-}$(Fig. 6).

\section{DISCUSSION}

The pathophysiological role of RNOS has received much attention since the discovery of the endogenous formation of NO $(38,39)$. Exposure of cells to NO delivered either as a bolus solution saturated with gaseous $\mathrm{NO}$ or from the decomposition of $\mathrm{NO}$ donor compounds results in little toxicity (23), unless the cells are exposed chronically to very high amounts of $\mathrm{NO}$ ( $>5$ $\mathrm{mM}$ total) (40). However, in the presence of oxygen or superoxide, RNOS such as $\mathrm{N}_{2} \mathrm{O}_{3}$ and $\mathrm{ONOO}^{-}$are formed. These reactive molecules can modify numerous macromolecules, including DNA, lipids, and proteins 
(41). The chemistry involving these intermediates is often invoked as the causative agent in numerous deleterious biological effects of NO.

Recent reports suggest that another RNOS, $\mathrm{NO}^{-}$, may be of critical importance in the biology of $\mathrm{NO}(14$, $15,42) . \mathrm{NO}^{-}$is the one-electron reduction species of NO. However, its formation in vivo through reduction is unlikely because oxygen, which is generally in 100 times excess over NO, is more easily reduced than NO (18). However, $\mathrm{NO}^{-}$may beformed (1) directly, through the enzymatic activity of NOS $(14,15) ;(2)$ indirectly, via of HO-Arg mediated by hydrogen peroxide/hemoprotein (17); or (3) through the heterolytic decomposition of S-nitrosothiols (20).

Angelis's salt yields $\mathrm{N}_{2} \mathrm{O}$ by the formation of $\mathrm{NO}^{-}$ (Eqs. [1] and [2]), unlike related amine NONOate compounds such as DEA/NO which yield exclusively NO.

$$
\begin{aligned}
\mathrm{N}_{2} \mathrm{O}_{3}^{-2}+\mathrm{H}^{+} & \rightarrow \mathrm{HNO}+\mathrm{NO}_{2}^{-} \\
2 \mathrm{HNO} & \rightarrow \mathrm{N}_{2} \mathrm{O}+\mathrm{H}_{2} \mathrm{O}
\end{aligned}
$$

It has been proposed that the primary decomposition product of AS at neutral pH is singlet $\mathrm{NO}^{-}$(26), though other intermediates have been proposed (43). Two re cent reports have suggested that $\mathrm{NO}^{-}$is a product of NOS $(14,15)$. One report showed that similar concentrations of SOD were required for NO production from either AS or NOS, which suggests that $\mathrm{NO}^{-}$is in fact produced by NOS (15). It has been shown that SOD

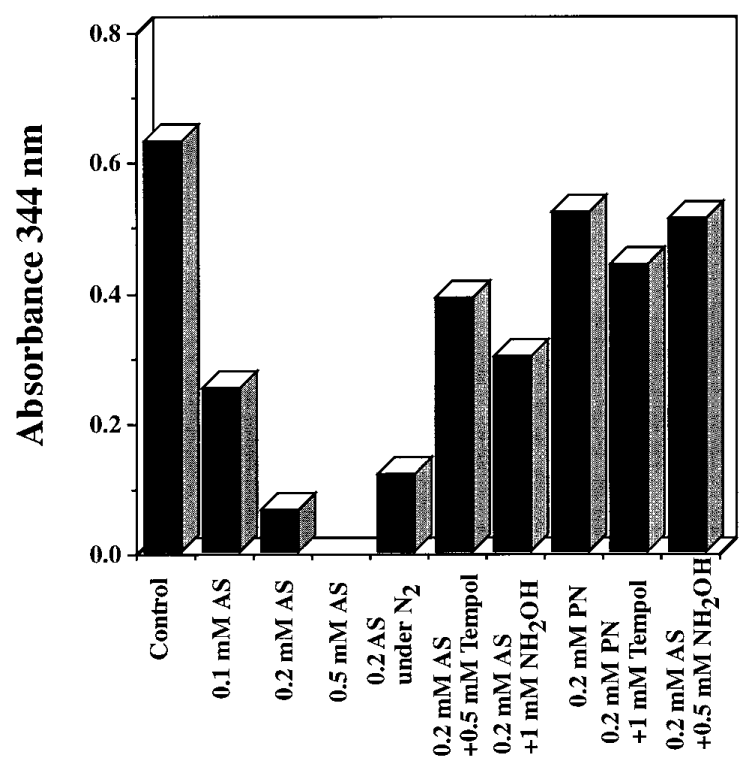

FIG. 6. Oxidation of NADPH as measured by loss of absorbance at $340 \mathrm{~nm}$ with increasing amounts of AS $(0,0.1,0.2,0.5 \mathrm{mM}), 0.2 \mathrm{mM}$ AS/Tempol, $0.2 \mathrm{mM} \mathrm{AS} / \mathrm{NH}_{2} \mathrm{OH}$. These values were compared to 0.2 $\mathrm{mM} \mathrm{ONOO}^{-}, 0.2 \mathrm{mM}$ PN/0.5 mM Tempol and $0.5 \mathrm{mM}$ PN/0.5 mM $\mathrm{NH}_{2} \mathrm{OH}$. Samples were done in triplicate and incubated for $30 \mathrm{~min}$. Errors were less than 5\%. can undergo one electron reduction to convert $\mathrm{NO}^{-}$to NO (Eq. [3]) (44, 45).

$$
\mathrm{NO}^{-}+\operatorname{SOD}\left(\mathrm{Cu}^{2+}\right) \rightarrow \mathrm{NO}+\mathrm{SOD}\left(\mathrm{Cu}^{+}\right)
$$

The similarity between the SOD concentration required to form NO from NOS and AS, as well as our observation that $\mathrm{NO}$ is often cytoprotective (4), prompted us to examine whether $\mathrm{NO}^{-}$would prove to be cytotoxic. Our results indeed demonstrate that $\mathrm{NO}^{-}$ delivered by AS is orders of magnitude more toxic than equal concentrations of $\mathrm{NO}$ delivered by a similar NO donor DEA/NO (Fig. 1) $(5,6)$.

Addition of an electron acceptor such as [Fe(III) $\left.(\mathrm{CN})_{6}\right]^{3-}$ or Tempol markedly protected $\mathrm{V} 79$ cells from the toxic effects of $\mathrm{NO}^{-}$. I nitial experiments using an $\mathrm{NO}^{-}$sensitive electrode showed that the presence of either electron acceptor, $\left[\mathrm{Fe}(\mathrm{III})(\mathrm{CN})_{6}\right]^{3-}$ or Tempol, resulted in the release of NO from AS (data not shown). This can readily be explained by the oxidation of $\mathrm{NO}^{-}$ by either oxidizing agents (Eqs. [4] and [5]):

$$
\begin{gathered}
\mathrm{NO}^{-}+\left[\mathrm{Fe}(\mathrm{III})(\mathrm{CN})_{6}^{3-} \rightarrow \mathrm{NO}+\mathrm{Fe}(\mathrm{II})(\mathrm{CN})_{6}^{4-}\right. \\
\mathrm{NO}^{-}+\mathrm{Tempol} \rightarrow \mathrm{NO}+\text { Tempol }-\mathrm{H}(\mathrm{TPH})
\end{gathered}
$$

Tempol is a stable free radical which loses its characteristic electron spin resonance (ESR) signal upon reduction. Preliminary ESR studies revealed that the conversion of Tempol to the ESR silent TPH follows the decomposition rate of AS (data not shown). Furthermore, there was no significant difference of reduction rate at different concentrations of Tempol. This would indicate there is no direct oxidation of AS by Tempol and suggests that the interception of $\mathrm{NO}^{-}$by Tempol generates NO. Comparison of Fig. 2A with 2B suggests that part of the conversion reaction of $\mathrm{NO}^{-}$ to NO by ferricyanide may occur through the direct oxidation of AS. Direct oxidation of AS also leads to NO formation (18). The importance of the interconversion of $\mathrm{NO}^{-}$to $\mathrm{NO}$ is that the cytotoxicity of $\mathrm{NO}^{-}$can be compared to that of $\mathrm{NO}$ by exposing cells to AS in the presence and absence of either $\left[\mathrm{Fe}(\mathrm{III})(\mathrm{CN})_{6}\right]^{3-}$ or Tempol.

F urther comparison with $\mathrm{NO}^{-}$and other reactive intermediates can be made. The production of simultaneous $\mathrm{NO} / \mathrm{O}_{2}^{-}$produces $\mathrm{ONOO}^{-}$and other RNOS. It has been proposed that the $\mathrm{NO} / \mathrm{O}_{2}{ }^{-}$reaction is one of the major causative agents in numerous pathophysiological conditions. The hypothesis is based on bolus doses of $\mathrm{ONOO}^{-}$. However, several studies have shown that cogeneration of $\mathrm{NO} / \mathrm{O}_{2}{ }^{-}$under biological conditions is not appreciably toxic (4). The NO donor SIN-1, which produces both $\mathrm{O}_{2}{ }^{-}$and $\mathrm{NO}$, added at concentrations up to $5 \mathrm{mM}$, produces little or no toxicity mammalian cells (46). A comparison of similar conditions showed that exposure of $\mathrm{V} 79$ cells to the super oxide generating system, hypoxanthine/xanthine oxidase, and 0.01-1 mM 
DEA/NO (1 mM DEA/NO gives equimolar NO as $2 \mathrm{mM}$ AS gives $\mathrm{NO}^{-}$) does not result in appreciable toxicity (4), while addition of hypoxanthine/xanthine oxidase al one was toxic. Ther efore, simultaneous generation of $\mathrm{NO}$ and $\mathrm{O}_{2}{ }^{-}$is considerably less toxic than $\mathrm{NO}^{-}$, despite the presence of the toxic RNOS, peroxynitrite. In fact, under these conditions $\mathrm{NO}$ is protective against toxicity mediated by ROS.

We examined the cellular factors which may govern the extent of $\mathrm{NO}^{-}$toxicity. Reduced glutathione (GSH) is crucial for the detoxification of the RNOS, $\mathrm{N}_{2} \mathrm{O}_{3}$, and $\mathrm{ONOO}^{-}$(47), as well as for $\mathrm{H}_{2} \mathrm{O}_{2}$. GSH appears to play a similar role in the case of $\mathrm{NO}^{-}$. Depletion of intracellular GSH resulted in a considerable increase in the toxicity of AS. It has been shown that $\mathrm{NO}^{-}$derived from AS readily oxidizes thiols (43). In fact, in preliminary competitive studies, we have found that $\mathrm{NO}^{-}$reacts with thiols 100 times more rapidly than other RNOS such as $\mathrm{ONOO}^{-}$(data not shown). The chemical and cellular results support the notion that GSH is critical in the initial detoxification of $\mathrm{NO}^{-}$. Examination of GSH levels in Table 1 shows that while exposure of cells to $1 \mathrm{mM}$ AS was not toxic, this concentration of AS reduced GSH as much as $80 \%$. It may be surmised that $\mathrm{NO}^{-}$first depletes intracellular GSH, which then renders other cellular targets susceptible to the chemistry of $\mathrm{NO}^{-}$.

Another important aspect of our observations is their implication for the chemistry of the L-Arginine:NO pathway under different pathophysiological conditions. The depletion of GSH by endogenously produced $\mathrm{NO}^{-}$ may render cells susceptible to other cytotoxic agents. For instance, intracellular GSH abates the toxicity of peroxide and RNOS under conditions of increased oxidative stress. The concomitant formation of $\mathrm{NO}^{-}$in the presence of oxidative stress may enhance levels of peroxide toxicity since GSH would not be available to detoxify $\mathrm{H}_{2} \mathrm{O}_{2}$. In a previous report, AS markedly enhanced the cytotoxicity of hydrogen peroxide (6). Therefore, even at subtoxic doses of $\mathrm{NO}^{-}$, a cell can be rendered susceptible to damage by oxidative stress.

Studies on oxidative stress involving $\mathrm{H}_{2} \mathrm{O}_{2}$ suggest that redox metals are critical for cellular damage (48). In the presence of metal chelators such as DF or DETAPAC, these Fenton-driven reactions are abated. However, these metal chelators did not protect cells exposed to AS. The lack of protection by metal chelators suggests that ROS formed from hydrogen peroxide are not involved in the toxicity of $\mathrm{NO}^{-}$.

While ROS derived from metals may not be required, oxygen itself appears to be necessary for the cytotoxic effect of $\mathrm{NO}^{-}$. There are a number of possible explanations for this. One is that $\mathrm{NO}^{-}$may initiatelipid peroxidation which is propagated by $\mathrm{O}_{2}$ (48). We have found that hydroperoxide toxicity is reduced in the absence of $\mathrm{O}_{2}$, suggesting that lipid peroxidation might play a role in the toxicity of alkylhydroperoxides (data not shown). Trolox, a water soluble antioxidant that may abate lipid peroxidation (48) afforded no protection against AS-toxicity (data not shown). Another possibility is that $\mathrm{NO}^{-}$can react with oxygen to form $\mathrm{ONOO}^{-}$. However, $\mathrm{NO}^{-}$is released from AS in the singlet state (26), which may not have a sufficient rate of reaction with triplet oxygen to form $\mathrm{ONOO}^{-}(49)$. We found in preliminary experiments that the oxidation chemistry of dihydrorhodamine with $\mathrm{ONOO}^{-}$or the intermediate produced by AS are similar. However, we also found that AS hydroxylates benzoate 10 times more efficiently than $\mathrm{ONOO}^{-}$and, unlike the latter, does not appear to nitrate phenols (data not shown). These results may suggest that either the formation of peroxynitrite is modified or there exists another intermediate. We are currently examining the chemical mechanisms of these reactions.

The finding that AS induces double strand breaks in cells is surprising, especially since neither $\mathrm{ONOO}^{-}$nor $\mathrm{H}_{2} \mathrm{O}_{2}$ induce this type of cellular damage. These strand breaks occur from the chemistry associated with $\mathrm{NO}^{-}$ and are not mediated by peroxide/metal-mediated oxidation. This activity of AS suggests that neither $\mathrm{ONOO}^{-}$nor $\mathrm{H}_{2} \mathrm{O}_{2}$ is the primary chemical species responsible for DNA damage. Similar to the effects of ionizing radiation and some chemotherapeutic drugs such Adriamycin, $\mathrm{NO}^{-}$appears to be effective in causing in this type of DNA damage.

Our findings may explain some of the discrepancies in the literature as to the protective or deleterious effects of NO in biological systems. While NO can abate the toxicity of peroxides via reactions with radicals and other components of the Fenton reaction, $\mathrm{NO}^{-}$actually enhances this toxicity. In vivo nitroxyl may by formed in one of three ways: (1) enzymatically, through the direct production of $\mathrm{NO}^{-}$from NOS; (2) through the incomplete oxidation of L-arginine to form HO-Arg which is further oxidized to form $\mathrm{NO}^{-}$, perhaps at a distal site from its source, or (3) via degradation of S-nitrosothiols. We hypothesize that NOS inhibitors would prevent the formation of $\mathrm{NO}^{-}$by any of these mechanisms. Finally, redox reactions with cellular components such as SOD or ferricytochrome c may be essential in maintaining the balance between $\mathrm{NO}^{-}$and NO in cells $(44,50)$. Redox-active enzymes such as SOD may not only be necessary to produce NO from NOS, but also to preserve the antioxidant status of the cell making it more resistant to oxidative stress mediated by a variety of toxic agents and intermediates.

\section{REFERENCES}

1. Choi, D. W. (1993) Proc. Natl. Acad. Sci. USA 53, 9741- 9743.

2. Wink, D. A., Grisham, M., Mitchell, J B., and Ford, P. C. (1996) Methods Enzymol. 268, 12- 31. 
3. Pryor, W. A., and Squadrito, G. L. (1996) Am. J. Phys. 268, L699- 721.

4. Wink, D. A., Hanbauer, I., Krishna, M. C., DeGraff, W., Gamson, J., and Mitchell, J.B. (1993) Proc. Natl. Acad. Sci. USA 90, 9813-9817.

5. Wink, D. A., Cook, J . A., Krishna, M. C., Hanbauer, I., DeGraff, W., Gamson, J ., and Mitchell, J . B. (1995) Arch. Biochem. Biophys. 319, $402-407$.

6. Wink, D. A., Cook, J ., Pacelli, R., DeGraff, W., Gamson, J ., Liebmann, J ., Krishna, M., and Mitchell, J . B. (1996) Arch. Biochem. Biophys. 331, 241- 248.

7. Rubbo, H., Radi, R., Trujillo, M., Telleri, R., Kalyanaraman, B., Barnes, S., Kirk, M., and Freeman, B. A. (1994) J . Biol. Chem. 269, 26066- 26075.

8. Hogg, N., Kalyanaraman, B., J oseph, J ., Struck, A., and Parthasarathy, S. (1993) FEBS Lett. 334, 170- 174.

9. Kanner, J ., Harel, S., and Granit, R. (1991) Arch. Biochem. Biophys. 289, 130- 136.

10. Gorbunov, N. V., Osipov, A. N., Day, B. W., Zayas-Rivera, B., Kagan, V. E., and Elsayed, N. M. (1995) Biochemistry 34, 66896699.

11. Wink, D. A., Cook, J . A., Kim, S., Vodovotz, Y., Pacelli, R., Kirshna, M. C., Russo, A., Mitchell, J.B., J ourd'heuil, D., Miles, A. M., and Grisham, M. B. (1997) J . Biol. Chem. 272, 1114711151.

12. Miles, A. M., Bohle, D. S., Glassbrenner, P.A., Hansert, B., Wink, D. A., and Grisham, M. B. (1996) J . Biol. Chem. 271, 4047.

13. Miles, A. M., Gibson, M., Krishna, M., Cook, J . C., Pacelli, R., Wink, D. A., and Grisham, M. B. (1995) Free Radical Res. 233, 379- 390.

14. Hobbs, A. J ., Fukuto, J . M., and I gnarro, L. J . (1994) Proc. Natl. Acad. Sci. USA 91, 10992-10996.

15. Schmidt, H.H., Hofmann, H., Schindler, U., Shutenko, Z. S., Cunningham, D. D., and Feelisch, M. (1996) Proc. Natl. Acad. Sci. USA 93, 14492- 14497.

16. Griffith, O. W., and Stuehr, D. J . (1995) Annu. Rev. Physiol. 57, 707-736.

17. Pufahl, R. A., Wishnok, J.S., and Marletta, M. A. (1995) Biochemistry 34, 1930-1941.

18. Wink, D. A., and Feelisch, M. (1996) Methods Nitric Oxide Res. 403- 412.

19. Williams, D. L. H. (1988) in Nitrosation, Cambridge Press, Oxford, UK.

20. Arnelle, D. R., and Stamler, J . S. (1995) Arch. Biochem. Biophys. 318, 279- 285.

21. Mitchell, J.B., Wink, D. A., DeGraff, W.,Gamson, J ., Keefer, L. K., and Krishna, M. C. (1993) Cancer Res. 53, 5845- 5848.

22. Pacelli, R., Wink, D. A., Cook, J . A., Krishna, M C., DeGraff, W., Friedman, N., Tsokos, M., Samuni, A., and Mitchell, J . B. (1995) J . Exp. Med. 182, 1469- 1479.

23. Wink, D. A., Hanbauer, I., Laval, F., Cook, J . A., Krishna, M. C., and Mitchell, J . B. (1994) Ann. N.Y. Acad. Sci. 738, 265- 278.

24. Misra, R. R., Hochadel, J . F., Smith, G. T., Waalkes, M. P., and Wink, D. A. (1996) Chem. Res. Toxicol. 10, 326- 332.

25. Cook, J . A., Krishna, M. C., Pacelli, R., DeGraff, W., Liebmann, J ., Russo, A., Mitchell, J . B., and Wink, D. A. (1997) Br. J . Cancer 76, 325- 334 .
26. Bonner, F. T., and Stedman, G. (1996) Methods Nitric OxideRes. 341- 356.

27. Akhtar, M.J ., Bonner, F. T., Hughes, M. N., Humphryes, E. J ., and Lu, C.-S. (1975) Inorg. Chem. 14, 558- 563.

28. Maragos, C. M., Morley, D., Wink, D. A., Dunams, T. M., Saavedra, J. E., Hoffman, A., Bove, A. A., I saac, L., Hrabie, J. A., and Keefer, L. K. (1991) J . Med. Chem. 34, 3242- 3247.

29. Beckman, J. S., Beckman, T. W., Chen, J ., Marshall, P. H., and Freeman, B. A. (1990) Proc. Natl. Acad. Sci. USA 87, 1620- 1624.

30. Russo, A., Mitchell, J . B., Finkelstein, E., DeGraff, W. G., Spiro, I. J ., and Gamson, J . (1985) Radiat. Res. 103, 232- 239.

31. Tietze, F. (1969) Anal. Biochem. 27, 502-522.

32. Ager, D. D., Dewey, W. C., Gardiner, K., Harvey, W., J ohnson, R. T., and Waldren, C. A. (1990) Radiat. Res. 122, 181- 187.

33. Stamato, T. D., and Denko, N. (1990) Radiat. Res. 121, 196- 205.

34. Christodoulou, D., Kudo, S., Cook, J. C., Krishna, M. C., Miles, A., Grisham, M. B., Murugesan, R., Ford, P. C., and Wink, D. A. (1996) Methods Enzymol. 268, 69-83.

35. Wink, D. A., Christodoulou, D., Ho, M., Krishna, M. C., Cook, J . A., Haut, H., Randol ph, J . K., Sullivan, M., Coia, G., Murray, R., and Meyer, T. (1995) Methods: Comp. Methods Enzymol. 7, 71- 77.

36. Zamora, R., Grzesiok, A., Weber, H., and Feelisch, M. (1995) Biochem. J . 312, 333- 339.

37. Mitchell, J . B., Samuni, A., Krishna, M. C., DeGraff, W. G., Ahn, M. S., Samuni, U., and Russo, A. (1990) Biochemistry 29, 28022807.

38. Rubbo, H., Darley-Usmar, V., and Freeman, B. A. (1996) Chem. Res. Toxicol. 9, 809-820.

39. Gross, S. S., and Wolin, M. S. (1995) Annu. Rev. Physiol. 57, 737- 769.

40. Tamir, S., Lewis, R. S., de Rojas Walker, T, Deen, W. M., Wishnok, J . S., and Tannenbaum, S. R. (1993) Chem. Res. Toxicol. 6, 895-899.

41. Wink, D. A., Hanbauer, I., Grisham, M. B., Laval, F., Nims, R. W., Laval, J ., Cook, J . C., Pacelli, R., Liebmann, J ., Krishna, M. C., Ford, M. C., and Mitchell, J . B. (1996) Curr. Topics Cell. Regul. 34, 159- 187.

42. Fukuto, J . M., Hobbs, A. J ., and I gnarro, L. J . (1993) Biochem. Biophys. Res. Commun. 196, 707- 713.

43. Doyle, M. P., Mahapatro, S. N., Broene, R. D., and Guy, J. K. (1988) J . Am. Chem. Soc. 110, 593- 599.

44. Murphy, M. E., and Sies, H. (1991) Proc. Natl. Acad. Sci. USA 88, 10860- 10864.

45. Feelisch, M., Ostrowski, J ., and Noack, E. (1989) J . Cardiovasc. Pharmacol. 14, S13-S22.

46. Farias-Eisner, R., Chaudhuri, G., Aeberhard, E., and Fukuto, J. M. (1996) J . Biol. Chem. 271, 6144-6151.

47. Wink, D. A., Nims, R. W., Darbyshire, J . F., Christodoulou, D., Hanbauer, I., Cox, G.W., Laval, F., Laval, J., Cook, J.A., Krishna, M. C., DeGraff, W., and Mitchell, J B. (1994) Chem. Res. Toxicol. 7, 519-525.

48. Halliwell, B., and Gutteridge, J . M. C. (1989) Free Rad. Biol. Med. 416-509.

49. Doyle, C. F., Hughes, M. N., Thompson, J . M., and Bonner, F. T. (1986) I norg. Chem. 25, 2676- 2677.

50. Kelm, M., Dahmann, R., Wink, D. A., and Feelisch, M. (1997) J . Biol. Chem., in press. 